\title{
Aquatic Surveys and Assessment of Selected Springs in the Centennial Valley, Beaverhead Co., MT
}

Prepared for the MT TNC Field Office by

David M. Stagliano

Aquatic Ecologist

March 2008

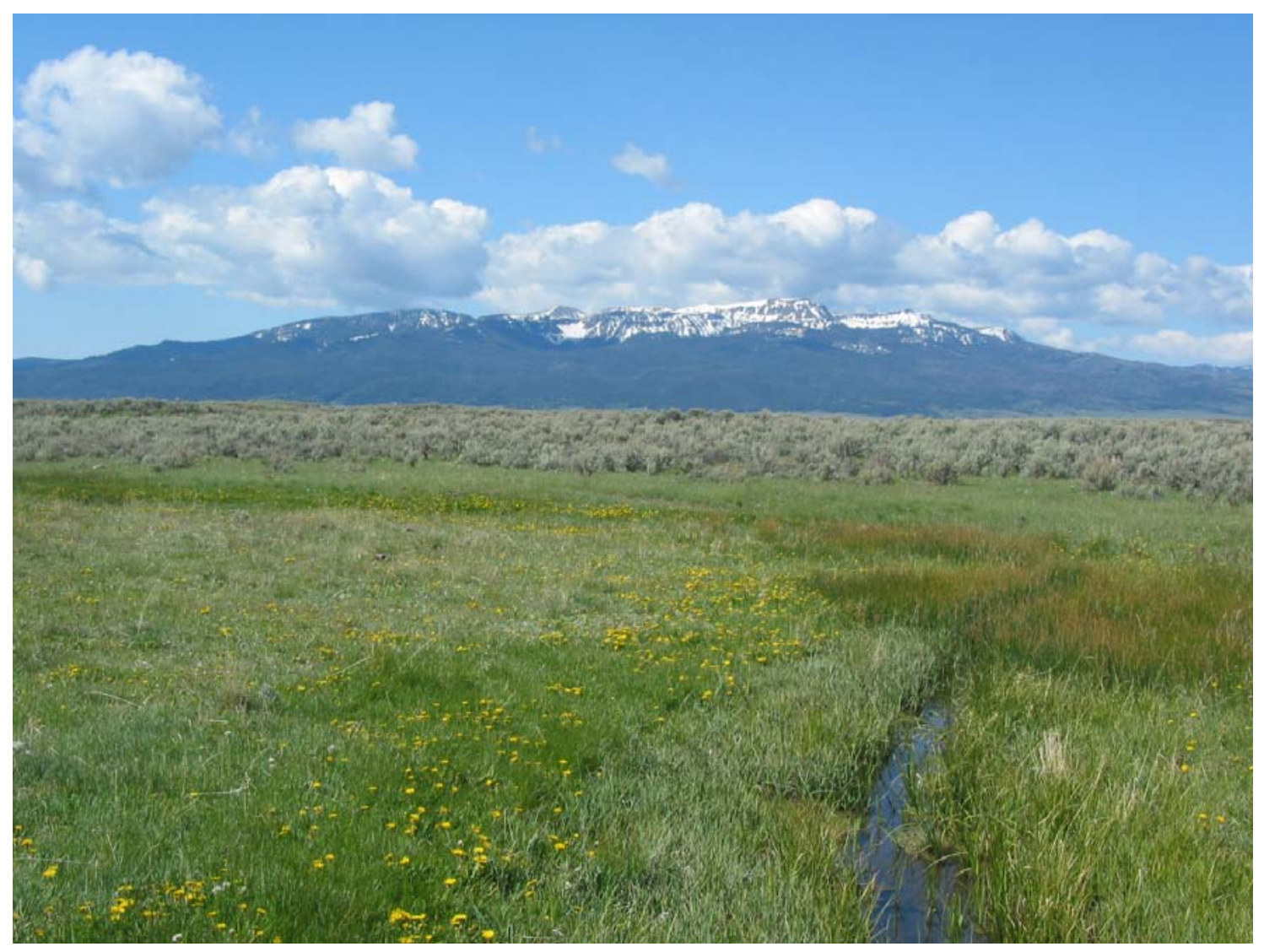

Tepee Creek looking South

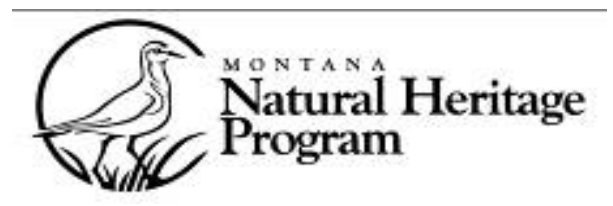

Natural Resource Information System

University of Montana 


\section{Project Summary}

Project goals of the Aquatic Survey and Assessment of selected springs in the Centennial Valley include: 1) to sample and assess aquatic community integrity based on macroinvertebrate, habitat sampling and basic water chemistry data, 2) to identify and interpret key macroinvertebrate indicators found at the sites, especially identifying SOC or unique taxa.

\section{Habitat Evaluations.}

On-site habitat assessments were conducted using the rapid assessment protocol by the BLM Aquatic Assessment (http://www1.usu.edu/buglab/forms/Bug\%20Protocol\%20form.pdf). Using this assessment, the reach was divided into 10 equally spaced transects. Parameters recorded at each were: wetted width, 3 channel depth measurements, large woody debris and riparian shading. Basic water chemistry parameters (temperature, $\mathrm{pH}$, conductivity, dissolved $\mathrm{O}_{2}$ ) were recorded prior to macroinvertebrate sampling using a Horiba $\mathrm{H}-10$ water monitor. The goal of these evaluations is to characterize local reach geomorphology, riparian and instream habitat, and other characteristics that influence aquatic community integrity. Sites ranking higher using these protocols are determined to have higher quality local-scale habitat.

\section{Macroinvertebrate Communities.}

Macroinvertebrates were collected from 10 designated transects across the reach with a 500micron D-frame dipnet. The method utilized was the EMAP Reach-Wide multi-habitat protocol outlined in Lazorchak (1998). All 10 samples were composited into a bucket, and the organisms were washed onto a 500-micron sieve, transferred to a 1 liter Nalgene bottle, labeled, preserved in 95\% ethanol and transported to the MTNHP lab in Helena for processing. The samples were processed (sorting, identification, and data analysis) by D. Stagliano following MT Department of Environmental Quality's protocols (MT DEQ 2005).

Macroinvertebrates were identified to the lowest taxonomic level, imported into EDAS (Jessup 2006), and biological metrics were calculated from the data using the newest multimetric macroinvertebrate (MMI) protocols (Jessup et al. 2005, Feldman 2006).

Table 1. Impairment determinations from the MMI and O/E (RIVPACS) models (taken from Jessup 2005, Feldman 2006).

\begin{tabular}{|l|l|l|l|} 
Ecoregion & RIVPACS & MMI & Impaiment Determination \\
\hline \hline Mountain & $\geq 0.8$ or $\leq 1.2$ & $\geq 63$ & Not impaired \\
& $<0.8$ or $>1.2$ & $<63$ & Impaired \\
\hline \multirow{2}{*}{ Low Valley } & $\geq 0.8$ or $\leq 1.2$ & $\geq 48$ & Wot impaired \\
& $<0.8$ or $>1.2$ & $<48$ & Impaired \\
\hline Eastern Flains & $\geq 0.8$ or $\leq 1.2$ & $\geq 37$ & Not impaired \\
& $<0.8$ or $>1.2$ & $<37$ & Impaired
\end{tabular}

Metric results were then scored using the Montana DEQ bioassessment criteria and each sample categorized as non-impaired or impaired according to threshold values (Table 3). The impairment threshold set by MT DEQ is $\mathbf{4 8}$ for the Low Mountain/ Valley Index, thus any scores above this threshold are considered unimpaired. Most of these Centennial sites should be categorized as Low Mountain / Valley sites, but we will run the metrics using the DEQ Mountain MMI as an alternate method. The macroinvertebrate MMI score is based upon a series of metrics that measure attributes of benthic macroinvertebrate communities regarding condition changes to a stream system (in the form of anthropogenic caused changes). 


\section{Sites}

All sites for this TNC assessment lie in Beaverhead Co., MT within former Centennial Livestock Ranch lands or adjacent to the ranch, including a DNRC State Section. Habitat assessments, water quality measurements, macroinvertebrate surveys were performed at 4 predetermined spring (stream) sites (per conversation with Nathan Korb) and an additional 2 stream sites. Three longitudinal sequence stream reach sites were sampled in Murphy Creek; while 2 were sampled in Fish to Metzel Creek. Three lotic types were delineated within the study area: Small Warm Spring Influenced Stream, Small Cold Springs and Small Foothills Streams.

Table 2. Spring Station information. Elevation in feet. Water temp in ${ }^{\circ} \mathrm{C}$, Cond=conductivity in $\mu \mathrm{s} / \mathrm{sec}$. $\mathrm{HBI}=$ Habitat Health assessment rank by riparian/stream evaluations $(++)$ good-excellent, $(+)$ fair-good, (-) poor, $(--)$ degraded. Bug Sample $(+)=$ taken at site, $(-)$-not taken.

\begin{tabular}{|c|c|c|c|c|c|c|c|c|c|}
\hline $\begin{array}{c}\text { Spring } \\
\#\end{array}$ & Name & Lat & Long & Elev & $\begin{array}{c}\mathrm{H}_{2} \mathrm{O} \\
\text { Temp }\end{array}$ & Cond & $\mathrm{pH}$ & HBI & $\begin{array}{l}\text { Bug } \\
\text { Sample }\end{array}$ \\
\hline $1 a$ & Murphy Creek headcut & 44.7006 & -111.8782 & 6831 & 27.2 & 598 & 7.58 & + & + \\
\hline 1 & $\begin{array}{l}\text { Murphy spring Right } \\
\text { Seep }\end{array}$ & 44.7002 & -111.8781 & 6826 & 28.4 & 605 & 7.58 & + & - \\
\hline $1 b$ & $\begin{array}{l}\text { Murphy Creek @ Side } \\
\text { Spring }\end{array}$ & 44.6997 & -111.8791 & 6820 & 29.4 & 564 & 7.64 & + & + \\
\hline 1c & $\begin{array}{l}\text { Murphy Creek below } \\
\text { culvert }\end{array}$ & 44.6987 & -111.8801 & 6799 & 26.8 & 594 & 8.05 & + & + \\
\hline 1 & $\begin{array}{l}\text { Murphy Creek Leaving } \\
\text { Ranch }\end{array}$ & 44.6949 & -111.8821 & 6742 & 24.8 & 587 & 7.3 & - & - \\
\hline 2 & Metzel Spring Source & 44.7024 & -111.8897 & 6810 & 26.7 & 597 & 8.18 & ++ & + \\
\hline 2 & Metzel seep downstream & 44.7023 & -111.8907 & 6800 & 22.8 & 602 & 8.26 & + & - \\
\hline 3 & Dulany Spring & 44.7039 & -111.8930 & 6824 & 22.9 & 606 & 7.99 & -+ & + \\
\hline 3 & $\begin{array}{l}\text { Combined springs-Fish } \\
\text { Creek meadow }\end{array}$ & 44.7015 & -111.8923 & 6764 & 14.5 & 620 & 8.05 & - & - \\
\hline 3 & $\begin{array}{l}\text { springs forming Fish } \\
\text { Creek meadow }\end{array}$ & 44.7000 & -111.8926 & 6752 & 14.9 & 622 & 8.08 & - & - \\
\hline 4 & Metzel Creek & 44.6754 & -111.7515 & 6758 & 13.2 & 399 & 8.8 & - & - \\
\hline $4 a$ & Metzel Creek above road & 44.6955 & -111.8971 & 6713 & 4.5 & 428 & 8.6 & - & + \\
\hline 4 & Fish Creek DNRC parcel & 44.6996 & -111.9081 & 6776 & 12.7 & 388 & 7.89 & - & - \\
\hline 4 & Fish Creek DNRC parcel & 44.7008 & -111.9108 & 6786 & 12.5 & 374 & 7.9 & - & - \\
\hline $4 b$ & $\begin{array}{l}\text { Fish Creek upstream } \\
\text { Willow riparian area }\end{array}$ & 44.7022 & -111.9161 & 6838 & 12.5 & 382 & 7.9 & + & + \\
\hline 5 & Tepee Creek & 44.6809 & -111.7537 & 6690 & 9.1 & 187 & 7.05 & - & + \\
\hline 6 & Hellroaring Creek Spring & 44.6157 & -111.5488 & 6817 & 7.5 & 269 & 6.78 & + & + \\
\hline
\end{tabular}




\section{Habitat Evaluations.}

\section{Results}

Highest site riparian habitat scores were measured in the Fish Creek willow dominated riparian reach on the DNRC state section. Lowest riparian integrity scores were also recorded from Fish Creek at a cattle crossing and a culvert site, and spring channels flowing to Metzel Creek. Tepee Creek scored moderately degraded. For the spring sites, Metzel spring ranked highest in ecological condition, Murphy spring sites were fair to good \& Dulany Spring was impacted by excavation, but the in-stream habitat ranked good and was similar to some sections of Murphy Creek springs. Water quality parameters, conductivity and $\mathrm{pH}$, were fairly uniform (fall within a normal range) across all spring sites ranging from low conductivity at Tepee Creek (187 $\mu \mathrm{s} / \mathrm{sec}$ ) to higher values at Metzel Cr. down from the confluence of the springs (622 $\mathrm{\mu s} / \mathrm{sec})$. Warmest temperature measured was $29.4^{\circ} \mathrm{C}$ at a side spring to Murphy Creek (Table 2).

\section{Fish Communities.}

Fish were not specifically targeted in our surveys, but we did record 2 fish species from the spring sites, the longnose dace (Rhinichthys cataractae) and the mottled sculpin (Cottus bairdii). Longnose dace were quite abundant in the warm spring reaches of Murphy Creek, Metzel and Dulany Springs; whereas the sculpin were only recorded in the cooler temperatures downstream from the warm water inputs (Fish and Metzel Creeks) were the water temps were below 22 degrees $\mathrm{C}$.

\section{Macroinvertebrate Communities.}

Overall, 74 macroinvertebrate taxa were reported from 9 samples within the TNC Centennial Spring and Creek Sites. Average macroinvertebrate taxa richness per site was 15.7 and the

\begin{tabular}{lcc}
\hline \multicolumn{1}{c}{ Unique “Cool” Taxon } & $\begin{array}{c}\text { Spring } \\
\text { Sites }\end{array}$ & $\begin{array}{c}\text { Fish Cr. } \\
\text { ups }\end{array}$ \\
\hline Stoneflies & & \\
$\quad$ Sweltsa sp. & - & + \\
$\quad$ Zapada cinctipes & - & + \\
Mayflies & & \\
$\quad$ Ameletus similior & - & + \\
$\quad$ Fallceon quilleri & + & - \\
Caddisflies & & \\
Rhyacophila brunnea gr. & + & + \\
Hesperophylax cf. designatus & + & - \\
Helicopsyche borealis & + & + \\
Ochrotrichia & + & - \\
Chimarra cf. utahensis & + & - \\
Neophylax rickeri & + & - \\
Neophylax splendens & + & - \\
Dragon/Damselflies & & \\
Argia & + & - \\
Ophiogomphus severus & + & - \\
True Flies & & \\
Pseudochironomus & + & - \\
Pagastia & + & - \\
Radotanypus & + & - \\
Eukiefferiella pseudomontana & + & - \\
\hline
\end{tabular}
highest taxa richness reported at Dulany

Spring was 22 taxa.

One introduced species were reported, the wide-ranging amphipod, Hyalella azteca (from all Murphy Creek spring sites). No new species or species of concern (SOC) were collected, although some interesting taxa are reported across most "warm-spring" sites that are not usually found in typical mountain stream habitats. These "spring-only" taxa included Chimarra cf. utahensis, Ochrotrichia, Helicopsyche borealis (see drawing), Fallceon quilleri and others (inset Table). Low numbers of individuals ( $<300$ ind.) were collected at Tepee, Dulany and Metzel Creek (above road culvert site). Since the stream area where macroinvertebrate collection takes place is fairly standardized, these low numbers usually indicate impairment in stream habitat or water quality. Using the Montana DEQ multimetric index (MMI), 8 of the 9 samples were ranked nonimpaired (good to excellent biological 


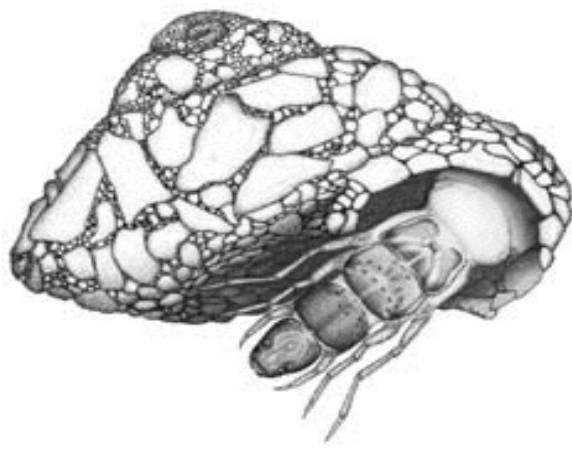

Drawing of Helicopsyche borealis, the snail-cased caddisfly, abundant in most Centennial warm-spring sites. C) Ethan Nadeau. integrity), and 1 was moderately impaired (Metzel Creek above the culvert) (Table 3). Although, Tepee Creek should also be ranked impaired by the MMI, but low numbers of organisms (red-flag) can eschew the metrics and cause score inflations. Tepee Creek also had the lowest number of taxa, most of which are tolerant to disturbance. The upstream reach of Fish Creek has the only macroinvertebrate community that resembles a high quality, cold-water trout stream community (Table 3). Hellroaring Spring also contained a fair number of sensitive cold-water taxa (Appendix A). Community results from the habitat, fish and macroinvertebrate surveys combined to rank the following sites from highest biological integrity to lowest within their aquatic ecological classification codes:

\section{Overall Aquatic Ecological System Site Condition (in order of highest to lowest integrity):}

Small Warm Spring Influenced Stream-(AES S003)-1) Murphy Creek Spring, 2) Metzel Spring, 3) Dulany Spring

Small Cold Spring Stream-(AES S003c)-1) Hellroaring Spring

Small Foothills Stream (AES D001)-1) Fish Creek (ups Willow Riparian Area), 2) Metzel

Creek at Culvert, 3) Metzel Creek at Road , 4) Metzel Creek (below meadow), 5) Fish Creek @ cattle crossing, 6) Tepee Creek

Table 3. Aquatic integrity ranking of all inventoried sites. Total number of invertebrates (\# of ind.), total taxa richness (T_Taxa), LVAL and MTN MMI scores, $(++)=$ high biological integrity, $(+)$ = good integrity, $(-)$ = slightly impaired, $(--)=$ moderate to severely impaired biological community. Shaded-cells represent good to excellent scores above set thresholds. $\mathrm{NC}=$ scores not recalculated.

\begin{tabular}{|c|c|c|c|c|c|c|}
\hline $\begin{array}{c}\text { Spring } \\
\#\end{array}$ & Name & T-Taxa & $\begin{array}{l}\text { \# of } \\
\text { Ind }\end{array}$ & $\begin{array}{l}\text { LVAL } \\
\text { MMI }\end{array}$ & $\begin{array}{l}\text { MTN } \\
\text { MMI }\end{array}$ & MMI Rank \\
\hline $1 a$ & $\begin{array}{l}\text { Murphy Creek Spring } \\
\text { headcut }\end{array}$ & 14 & 366 & 57.7 & nc & + \\
\hline $1 b$ & $\begin{array}{l}\text { Murphy Creek @ Side } \\
\text { Spring }\end{array}$ & 16 & 367 & 53.5 & nc & + \\
\hline 1c & Murphy Creek below culvert & 16 & 309 & 59.1 & nc & + \\
\hline 2 & Metzel Spring & 19 & 247 & 56.3 & nc & + \\
\hline 3 & Dulany Spring & 22 & *157 & 60.3 & nc & ++ \\
\hline $4 a$ & Metzel Creek above culvert & 10 & *147 & 28.4 & 18.4 & -- \\
\hline 4b & $\begin{array}{l}\text { Fish Creek upstream Willow } \\
\text { riparian area }\end{array}$ & 20 & 405 & 50.8 & 69.4 & + \\
\hline 5 & Tepee Creek & 9 & *102 & *76.6 & 41.1 & ?- \\
\hline 6 & Hellroaring Spring & 15 & 298 & 64.7 & nc & ++ \\
\hline
\end{tabular}




\section{Murphy Creek furthest upstream @ headcut}

Key Environmental Factors: Spring discharge permanence. Grazing-moderate-severe impacts, Hydrology--upstream dams or diversions in the watershed.

Ecoregion: Centennial Basin (17af) typical

Rare or Unique Species: No rare species or communities documented

Rare Features: A warm spring feed by numerous side springs in the high-elevation Centennial valley.

Introduced/Exotic Aquatic Species: The amphipoda, Hyalella azteca recorded

Overall Ecological Condition: Fair-with high restoration potential, cattle regime management

Moderately impacted by cattle grazing, grazer increasers in the riparian zone-Baltic rushes and Carex nebraskensis dominate.

Reach Geomorphology: Single thread spring channel dominated by cobbles, pebbles that are slightly embedded by fine sediments; a warm-spring flowing through lush, dense beds of bittercress and watercress.

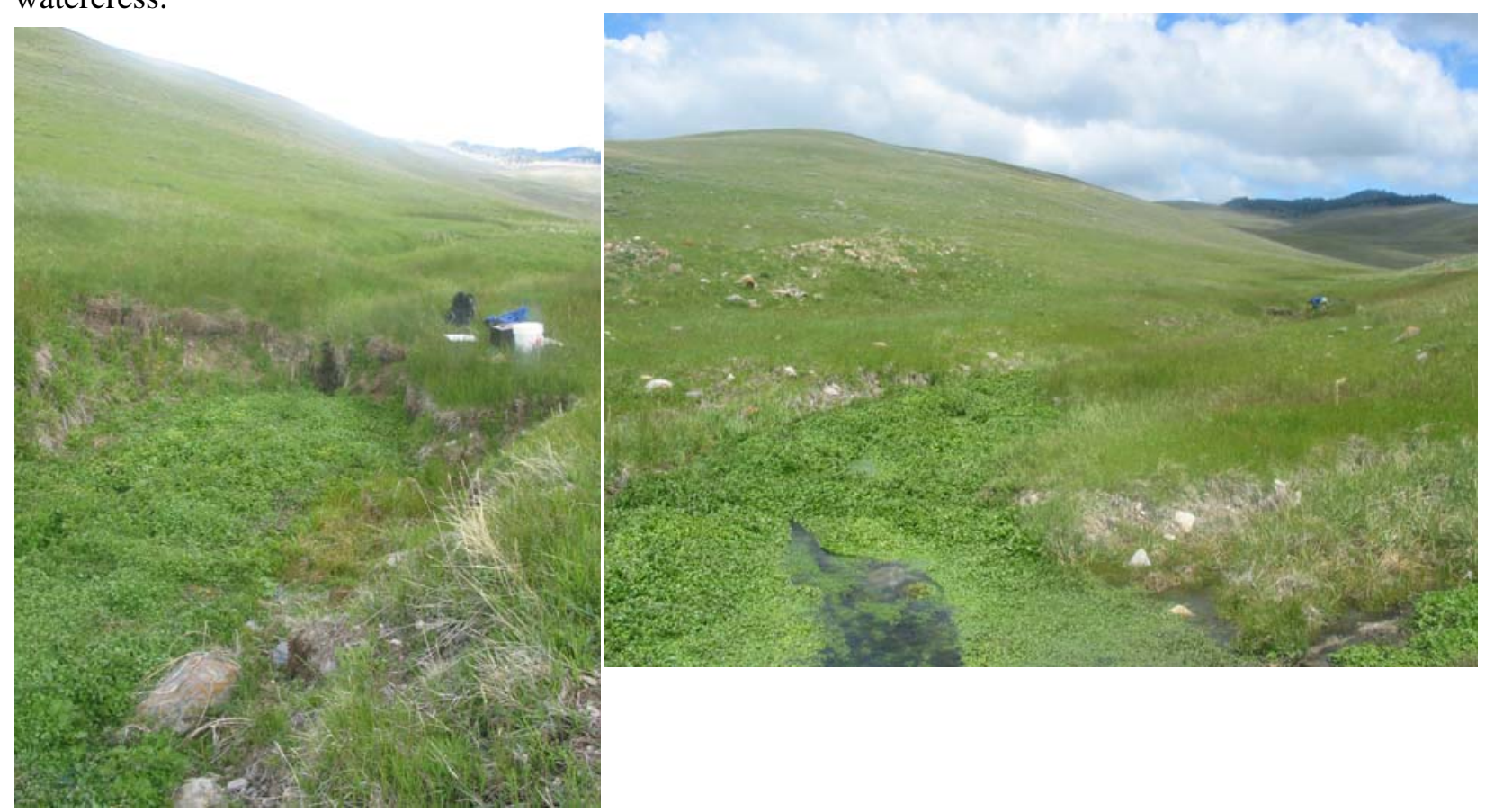

Fish Community: Longnose Dace, incidentally collected. Probably the only native species in the valley able to survive within a warm springs creek.

Fish Community Quality: IBI= 0 Expected fish community?

Macroinvertebrate Community: Good Macroinvertebrate Quality, dominated by the transitional cool-water stream community (Stagliano 2005), including some species not typically collected in mountain streams-Chimarra, Ochrotrichia, Helicopsyche borealis, Fallceon quilleri Macroinvertebrate Community Quality: MT MMI= 57.8 


\section{Murphy Creek mid-way to headcut @ side spring}

Key Environmental Factors: Spring discharge permanence. Grazing-moderate impacts, Hydrology-upstream dams or diversions in the watershed.

Ecoregion: Centennial Basin (17af) typical

Rare or Unique Species: No rare species or communities documented

Rare Features: A warm spring feed by numerous side springs in the high-elevation Centennial valley. Introduced/Exotic Aquatic Species: The amphipoda, Hyalella azteca recorded

Overall Ecological Condition: Fair-with high restoration potential, cattle regime management Moderately impacted by cattle grazing, grazer increasers in the riparian zone-Baltic rushes and Carex nebraskensis dominate.

Reach Geomorphology: Single thread spring channel dominated by cobbles, pebbles that are slightly embedded by fine sediments; flowing through lush, dense beds of bittercress and watercress.

Fish Community: Longnose Dace, incidentally collected. Probably the only native species in the valley able to survive within a warm springs creek.

Fish Community Quality: IBI= 0 Expected fish community?

Macroinvertebrate Community: Good Macroinvertebrate Quality, dominated by the transitional cool-water stream community (Stagliano 2005), including some species not typically collected in mountain streams-Chimarra, Ochrotrichia, Helicopsyche borealis, Fallceon quilleri Macroinvertebrate Community Quality: MT MMI= 53.5
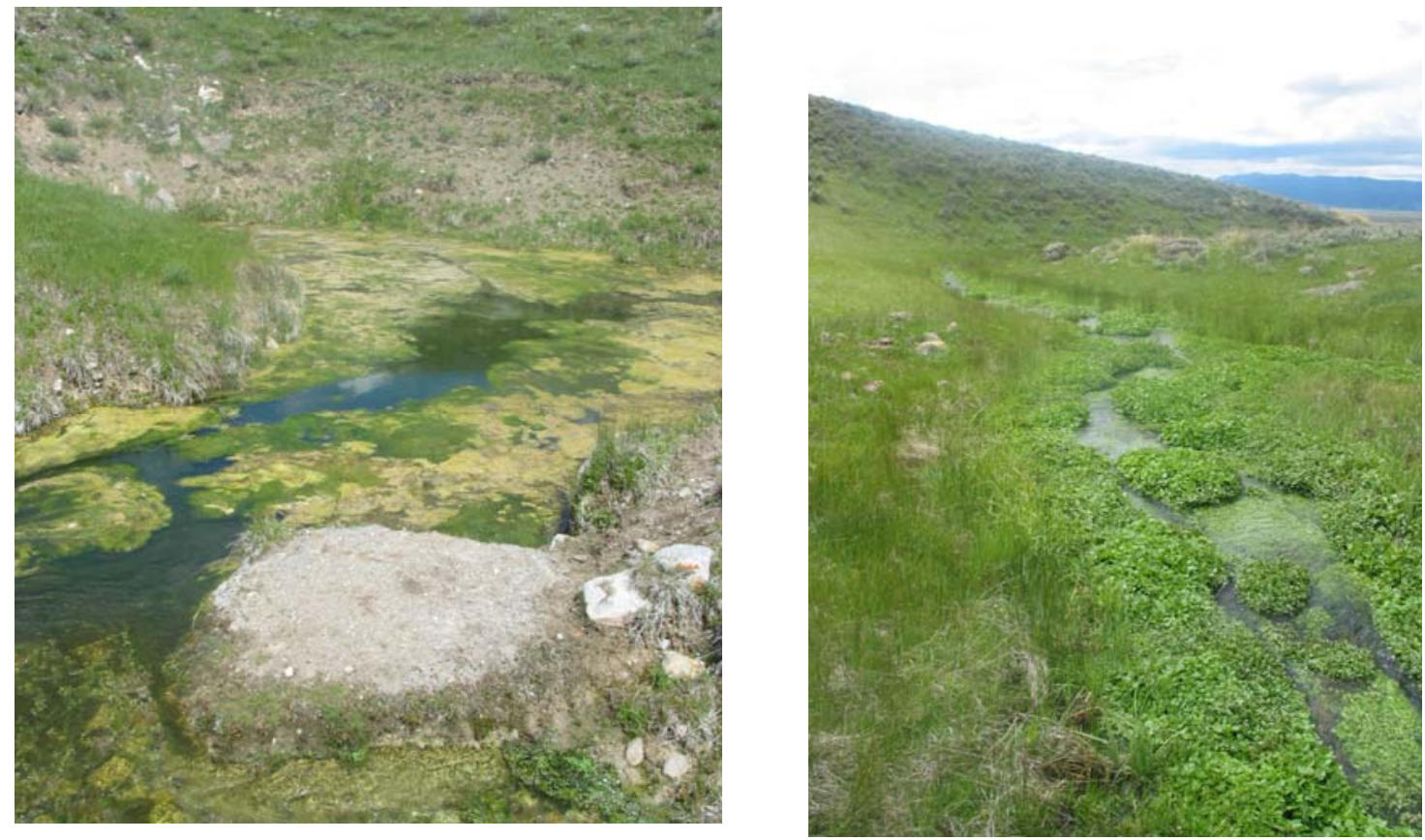

\section{Murphy Creek@ and down from culvert diversion}

Key Environmental Factors: Spring discharge permanence. Grazing-moderate impacts, Hydrology-upstream dams or diversions in the watershed.

Ecoregion: Centennial Basin (17af) typical

Rare or Unique Species: No rare species or communities documented

Rare Features: A warm spring feed by numerous side springs in the high-elevation Centennial valley. Introduced/Exotic Aquatic Species: The amphipoda, Hyalella azteca recorded

Overall Ecological Condition: Fair-Good-with high restoration potential, cattle management 
Reach Geomorphology: Single thread spring channel avg. wetted width $1.75 \mathrm{~m}$, dominated by cobbles $\&$ pebbles (a few boulders) that are slightly embedded by fine sediments; $60 \%$ riffle, 30run and 10\% pools. Less aquatic beds of bittercress and watercress like upstream.

Fish Community: Longnose Dace, incidentally collected and abundant. Probably the only native species in the valley able to survive within a warm springs creek.

Fish Community Quality: IBI= 0 Expected fish community?

Macroinvertebrate Community: Good Macroinvertebrate Quality, dominated by the transitional cool-water stream community (Stagliano 2005), including some species not typically collected in mountain streams - Chimarra, Ochrotrichia, Helicopsyche borealis, Fallceon quilleri Macroinvertebrate Community Quality: MT MMI= 59.2

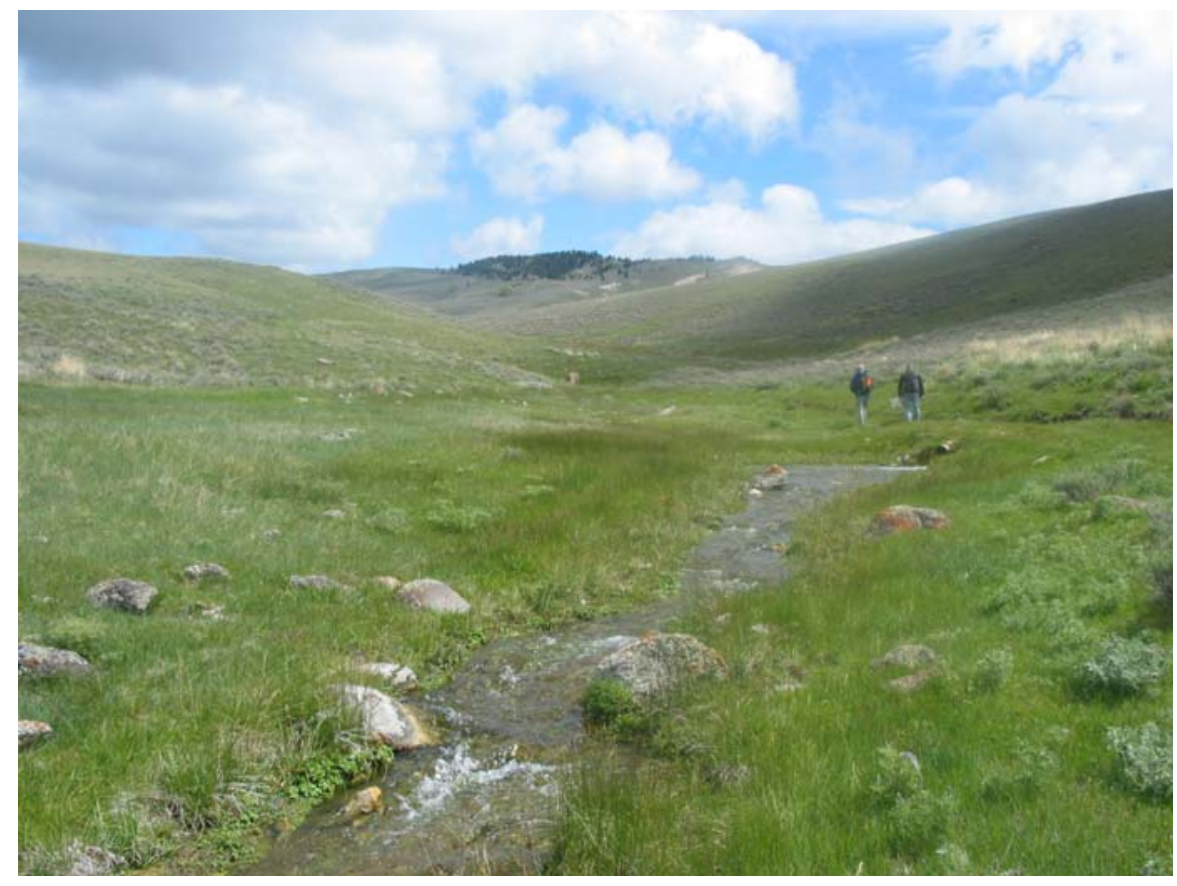

\section{Murphy Creek leaving the Ranch}

Key Environmental Factors: Spring discharge permanence. Grazing—moderate-severe impacts, Hydrology--upstream dams or diversions in the watershed.

Ecoregion: Centennial Basin (17af) typical

Rare or Unique Species: No rare species or communities documented

Rare Features: A warm spring feed by numerous side springs in a high valley.

Introduced/Exotic Species: The amphipoda, Hyalella azteca probably exists here.

Overall Ecological Condition: Fair-with high restoration potential, cattle regime management

Moderately impacted by cattle grazing, grazer increasers in the riparian zone-Baltic rushes and Carex nebraskensis dominated

Reach Riparian Ranking: BLM= NA EPA RBP= NA

Reach Geomorphology: Single thread warm spring channel avg. wetted width $2.75 \mathrm{~m}$, dominated by cobbles \& pebbles (a few boulders) that are slightly embedded by fine sediments; 30\% riffle, 50\% run and $20 \%$ pools. Less aquatic beds of bittercress and watercress like upstream. 


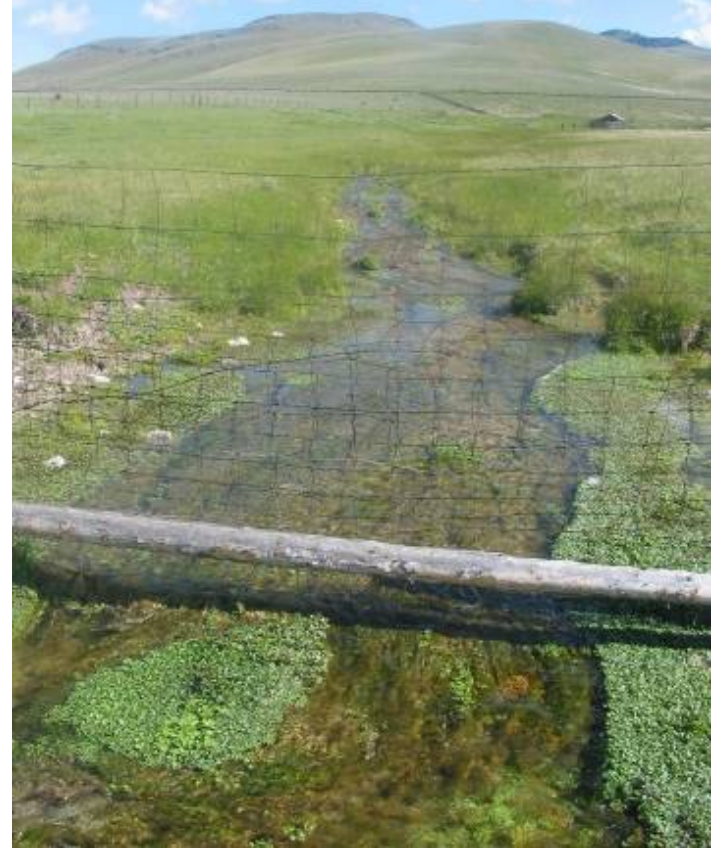

Fish Community: Longnose Dace, incidentally collected and abundant. Probably the only native species in the valley able to survive within a warm springs creek.

Fish Community Quality: IBI= 0 Expected fish community?

Macroinvertebrate Community: Did not collect a Macroinvertebrate sample here. Probably the same community as upstream sites (temps only decreased $3^{\circ}$ ), especially with the water veg. beds present---Chimarra, Ochrotrichia, Helicopsyche borealis, Fallceon quilleri

Macroinvertebrate Community Quality: MT MMI = NA

\section{Metzel Creek spring@ @ource}

Key Environmental Factors: Spring discharge permanence. Grazing - no noticeable impacts. Ecoregion: Centennial Basin (17af) typical Rare or Unique Aquatic Species: No rare species or communities documented

Rare Features: A warm spring arising out of a rocky outcrop in the high-elevation Centennial valley.

Introduced/Exotic Aquatic Species: None recorded Overall Ecological Condition: Good, with proper cattle grazing management

Reach Geomorphology: Single thread warm spring channel avg. wetted width $1.5 \mathrm{~m}$, dominated by cobbles \& pebbles (a few boulders) that are slightly embedded by fine sediments; $50 \%$ riffle, $40 \%$ run and $10 \%$ pool, flowing through lush, dense beds of bittercress and watercress. At spring orifice-

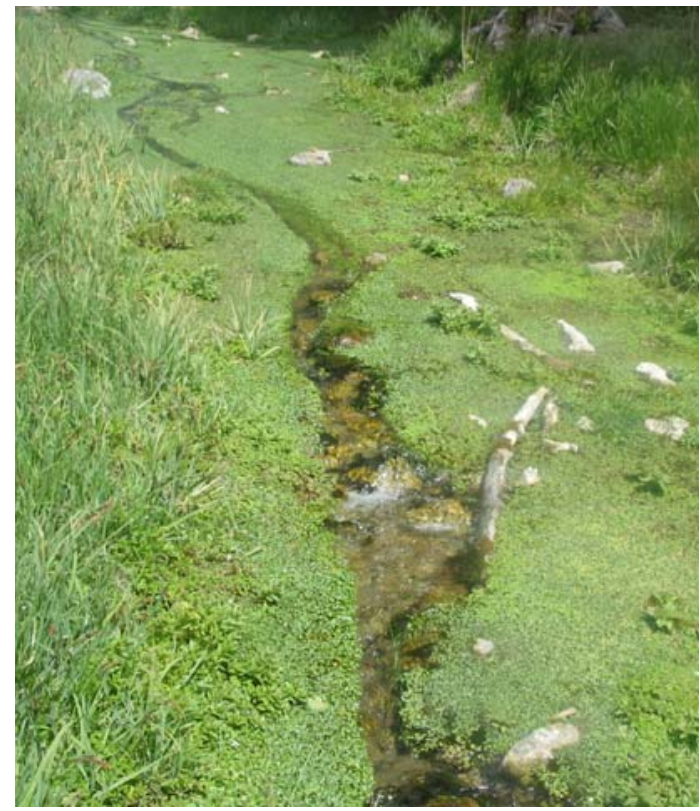

\section{3m WW \\ move \\ dispersed \\ spring area, 1 \\ degree \\ warmer-27.6 $6^{\circ}$ \\ Fish \\ Community: \\ Longnose \\ Dace, \\ incidentally}

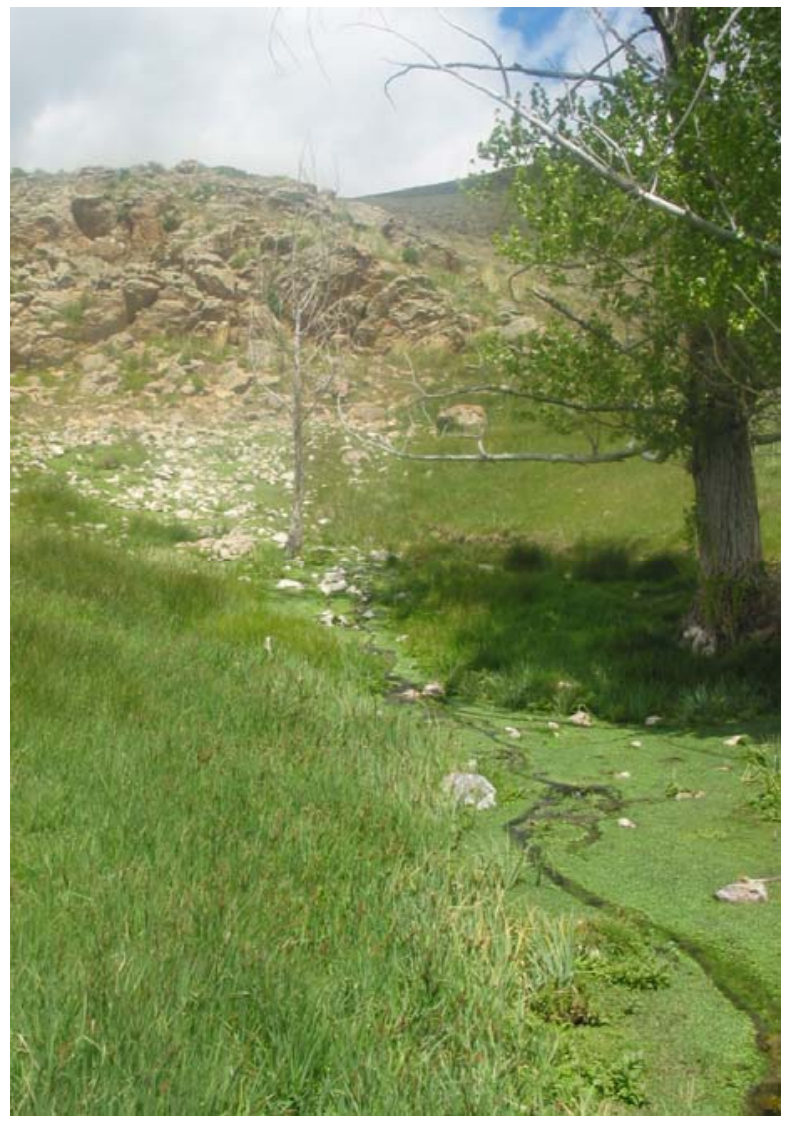

collected. Probably the only native species in the valley

able to survive within a warm springs creek. Fish

Community Quality: IBI= 0 Expected fish

community?

Macroinvertebrate Community: Good

Macroinvertebrate Quality, dominated by the

transitional cool-water stream community (Stagliano 
2005), including some rarely collected species not typical in mountain streams-Chimarra, Ochrotrichia, Helicopsyche borealis, Fallceon quilleri

Macroinvertebrate Community Quality: MT MMI= 56.3

\section{Metzel side channels after thrashed meadow}

Key Environmental Factors: Spring discharge permanence. Grazing-moderate-severe impacts, Hydrology--upstream dams or diversions, channelizations in the watershed.

Rare or Unique Species: No rare species or communities documented Rare Features: None

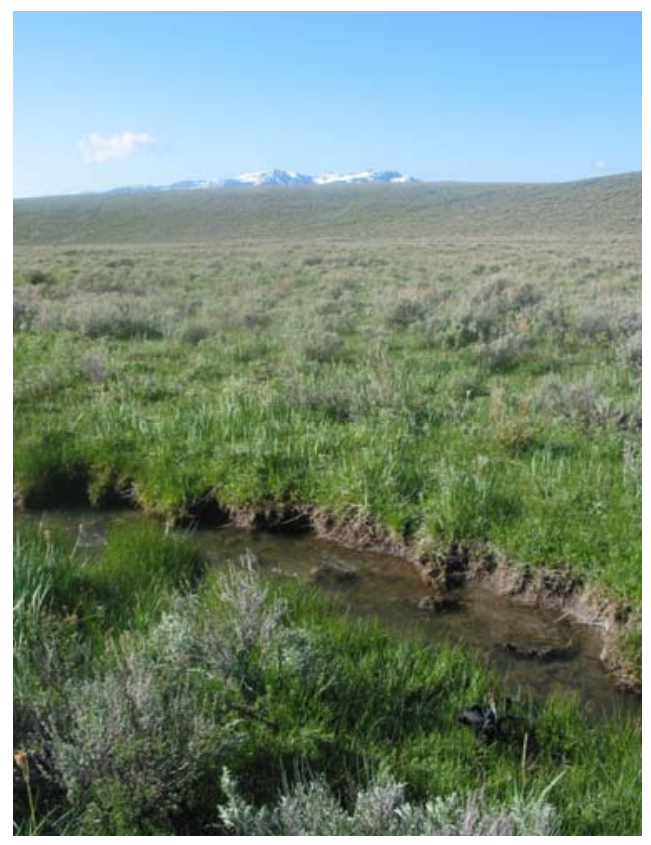

Introduced/Exotic Species: None recorded

Overall Ecological Condition:

Fair-Poor-with restoration

potential, restore main channel

flow, cattle grazing regime

management, banks sloughing-

needs riparian stabilization.

Moderately impacted by cattle

grazing, grazer increasers in the

riparian zone, Carex nebraskensis

dominated.

Reach Geomorphology: Single

thread channel, avg. wetted width

$2.0 \mathrm{~m}$, dominated gravels and silt

(a few cobbles) that are

moderately embedded by fine

sediments; $20 \%$ riffle, $60 \%$ run

and $20 \%$ pools.

Fish Community: Longnose

Dace, incidentally observed

Fish Community Quality: IBI= 0 Expected fish community?

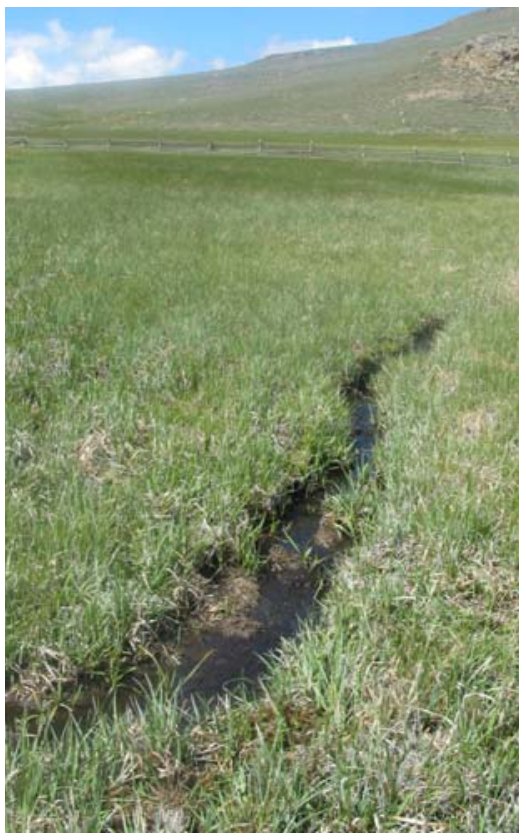

Macroinvertebrate Community: Did not collect a Macroinvertebrate sample here.

Macroinvertebrate Community Quality: na

\section{Dulany Spring@ source}

Key Environmental Factors: Spring discharge permanence, excavated out source area potentially adding sediments to the channel. Grazing —slight impacts.

Rare or Unique Aquatic Species: No rare species or communities documented

Rare Features: A warm spring arising out of an excavated outcrop in the Centennial valley.

Introduced/Exotic Aquatic Species: None recorded Overall Ecological Condition: Fair, with proper cattle grazing regime management

Reach Geomorphology: Single thread warm spring channel avg. wetted width $3.25 \mathrm{~m}$, dominated by pebbles and gravel (a few cobbles) that are slightly

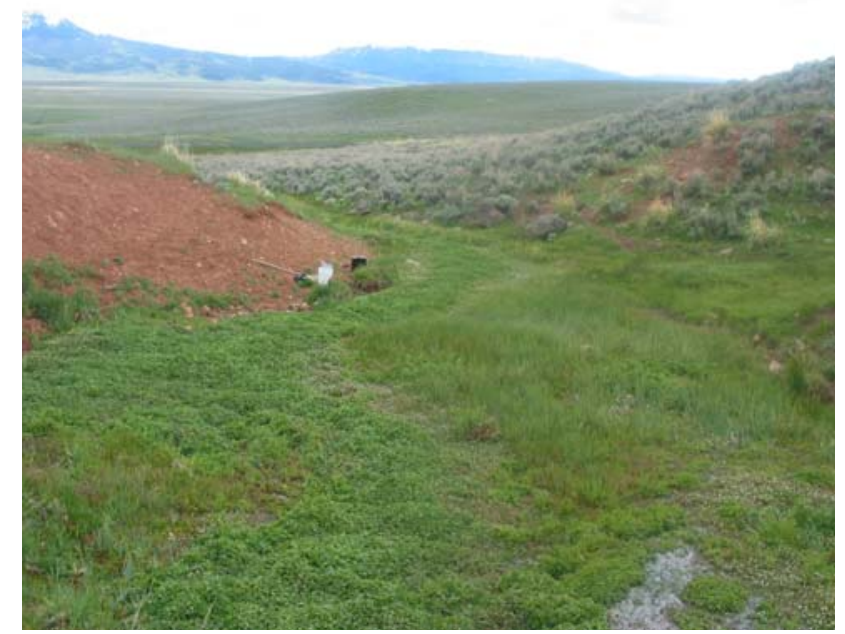
embedded by fine sediments; most top reach flowing through lush, dense beds of bittercress and watercress- $100 \%$ run. At spring orifice- $\mathrm{H} 2 \mathrm{O}$ warmer-25.6 ${ }^{\circ}$ 
Fish Community: Longnose Dace, incidentally collected. Probably the only native species in the valley able to survive within a warm springs creek.

Fish Community Quality: IBI= 0 Expected fish community?.

Macroinvertebrate Community: Good Macroinvertebrate Quality, dominated by the transitional cool-water stream community (Stagliano 2005), including some rarely collected species not typical in mountain streams-Chimarra, Ochrotrichia, Helicopsyche borealis, Fallceon quilleri

Macroinvertebrate MT MMI= 60.3

\section{Metzel Creek@ road and upstream from culvert}

Key Environmental Factors: Spring discharge permanence. Grazing-moderate impacts, Hydrology-upstream dams or diversions in the watershed, channelization of flows, Riparian stabilization.

Rare or Unique Species: No rare species or communities documented

Introduced/Exotic Aquatic Species: None recorded

Overall Ecological Condition: Fair-with high restoration potential, cattle grazing management

Reach Geomorphology: At the road, channel widened by cattle trampling (photo right $-2.5-3 m ~ W W$ ). Single thread spring channel avg. wetted width $2.5 \mathrm{~m}$, dominated by cobbles \& pebbles (a few boulders) that are slightlymoderately embedded by fine sediments; $40 \%$ riffle, $50 \%$ run and $10 \%$ pools.

Fish Community: Did not see any fish in this reach while

\section{sampling.}

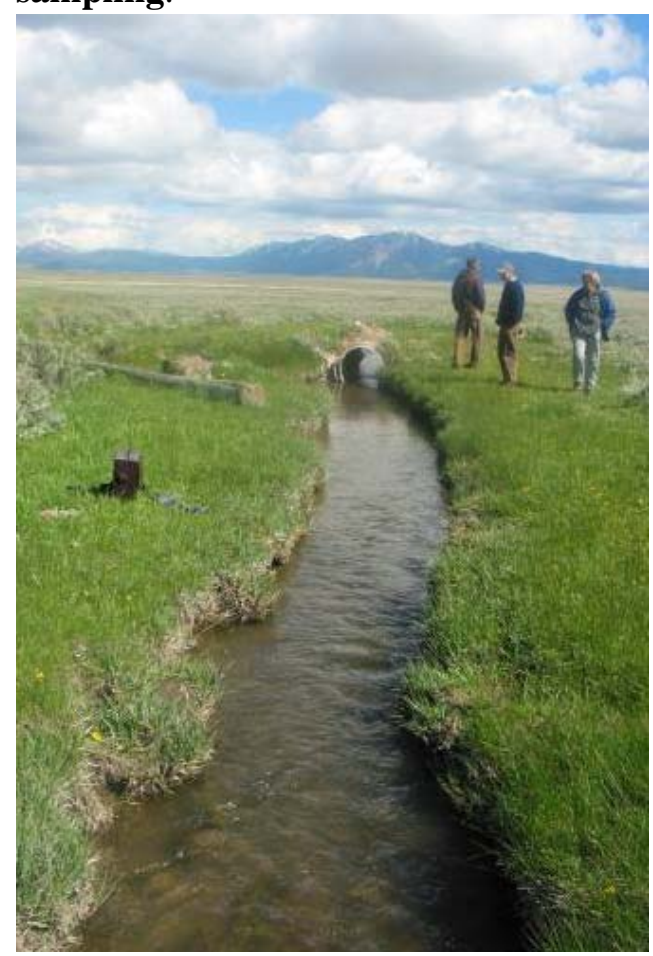

Fish Quality:

IBI= 0

Expected fish community would be presumably a trout stream community.

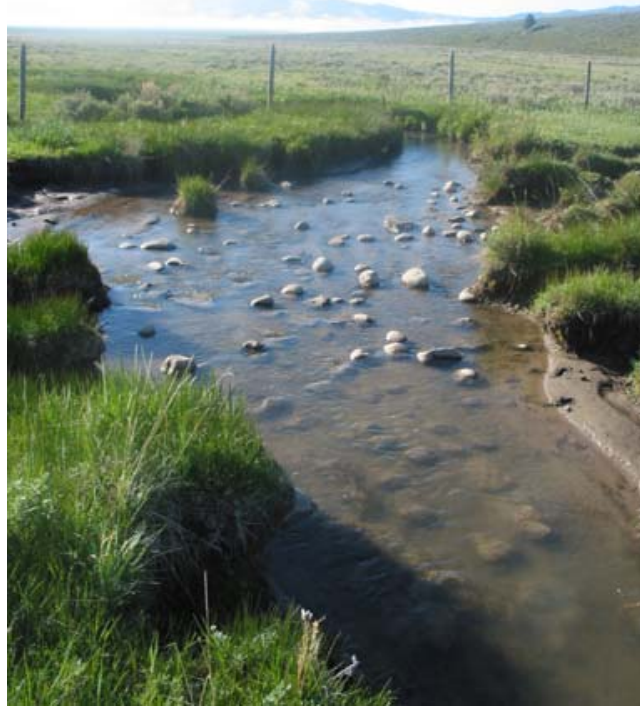

Macroinvertebrate Community: Poor Macroinvertebrate Quality, dominated by an impaired transitional coolwater stream community (Stagliano 2005).

Macroinvertebrate MT MMI= 28.4 


\section{Tepee Creek}

Key Environmental Factors: Grazing-moderate-severe impacts, Hydrology--upstream dams or diversions in the watershed-not likely.

Ecoregion: Centennial Basin (17af) typical Rare or Unique Species: No rare species or communities documented

Rare Features: No rare features documented Introduced/Exotic Aquatic Species: None recorded Overall Ecological Condition: Poor-with high restoration potential, cattle regime management Heavily impacted by cattle grazing, high livestock use index, thrashed and grazed riparian zone-

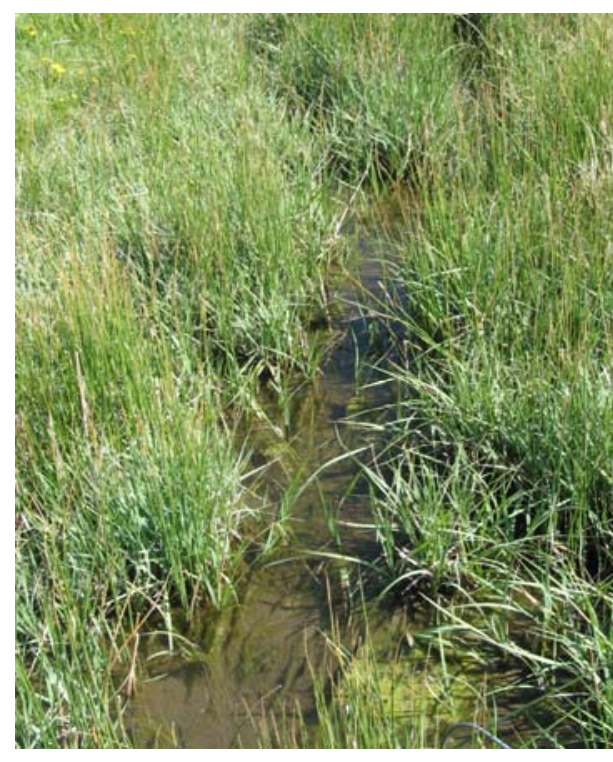

Baltic rushes and Carex nebraskensi $s$ dominates.

Reach Geomorphol

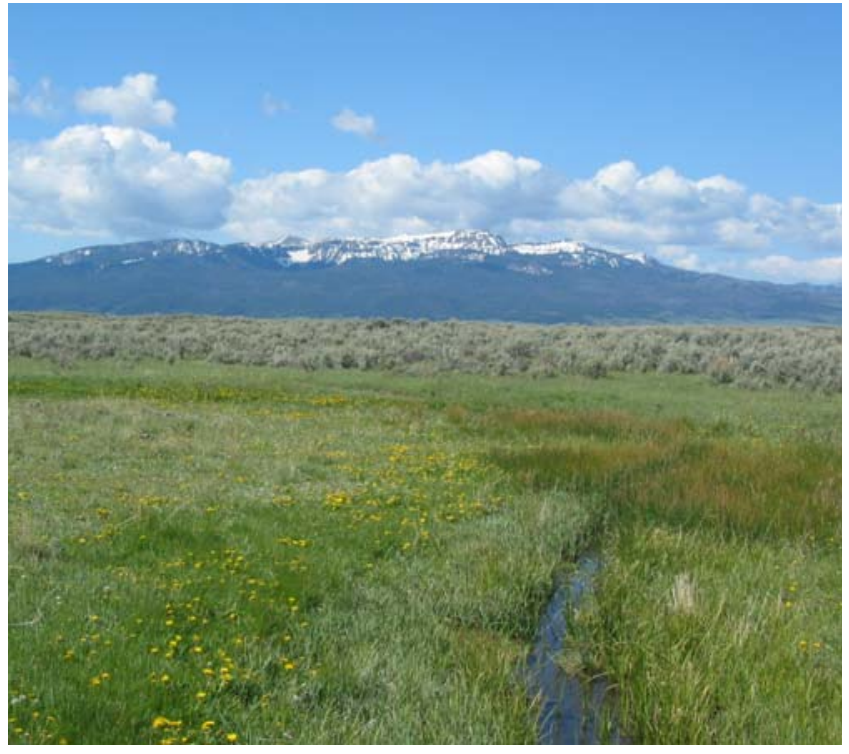
ogy: Single thread spring channel dominated by $100 \%$ fine sediment; a cool-spring flowing into the sand dunes area of the Centennial before disappearing in the sediments and eventually joining with Red Rock Ponds. Surrounding bank materials are similar to the channel bed materials.

Fish Community: No fish species collected or sighted in the reach. Expected fish for this stream type have not been met.

Fish Community Quality: IBI $=0$ O/E $=0 / 2.7$ or $0 \%$ of the expected fish community

Macroinvertebrate Community: Poor Macroinvertebrate Quality, dominated by tolerant species. Macroinvertebrate Quality: MT MMI= Eschewed value due to low invertebrate numbers

\section{Hellroaring Spring}

Ecoregion: Centennial Basin (17af) typical

Rare or Unique Species: No rare species or communities documented

Rare Features: No rare features documented

Introduced/Exotic Aquatic Species: None recorded

Reach Riparian Ranking: BLM= NA EPA RBP= NA

Reach Geomorphology: Cobble-boulder dominated, $1.5 \mathrm{~m}$ channel width, cold-spring feeding into a series of ponds before joining Hellroaring Creek approximately $1 / 2$ mile downstream. A high-integrity, cold-spring macroinvertebrate community collected.

Fish Community: No fish species were collected, none expected.

Fish Community Quality: IBI= 0 No expected fish community

Macroinvertebrate Community: A cold-water macroinvertebrate community with indicator species similar to the pristine mountain community (Stagliano 2005).

Macroinvertebrate Community Quality: MMI= 64.7 

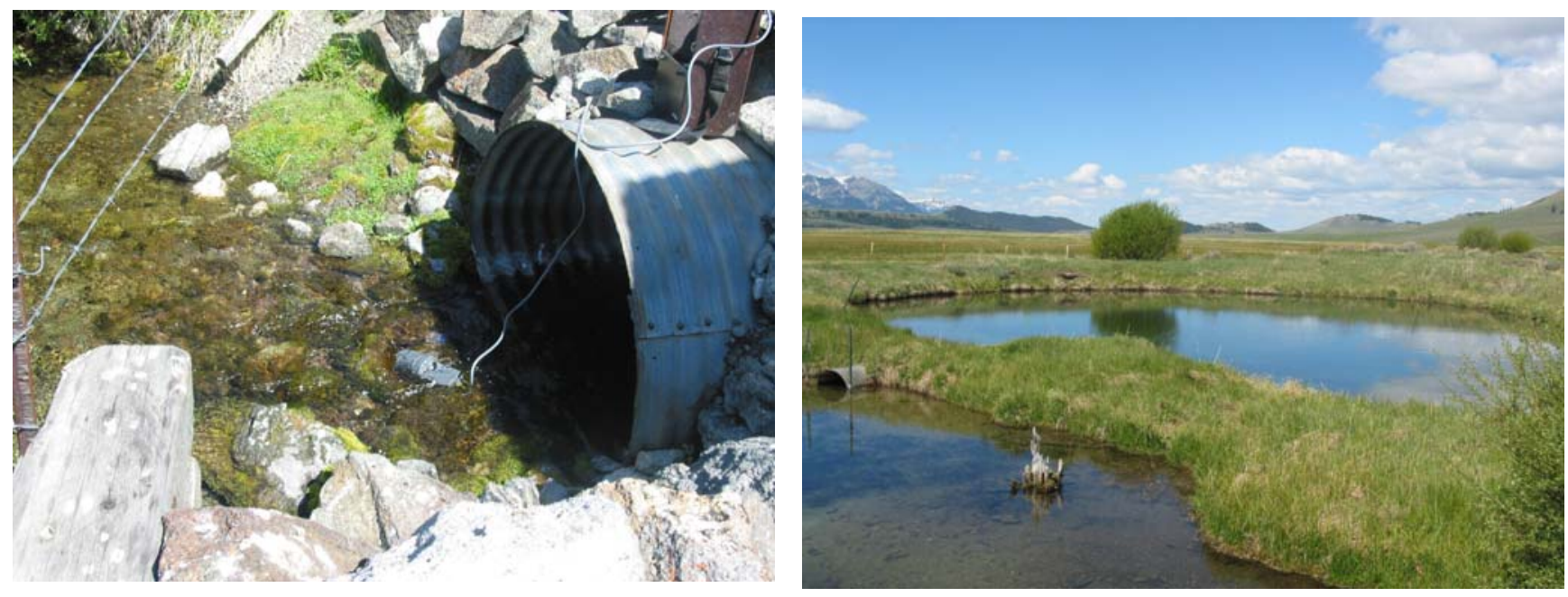

\section{Acknowledgements}

We would like to thank The Montana Field Office of the Nature Conservancy, especially Nathan Korb and Brian Martin (MT). Accommodations were supplied by the Centennial Livestock Ranch house owned by the Nature Conservancy. Field work was assisted by Linda Vance and Scott Mincemoyer.

All photos in the report were taken by MTNHP personnel, unless otherwise noted.

\section{Literature Cited}

Feldman, D. 2006. Interpretation of New Macroinvertebrate Models by WQPB. Draft

Report. Montana Department of Environmental Quality, Planning Prevention and

Assistance Division, Water Quality Planning Bureau, Water Quality Standards Section.1520 E.

$6^{\text {th }}$ Avenue, Helena, MT 59620. 14 pp.

Holton, G. D., and H. E. Johnson. 2003. A field guide to Montana fishes, 3rd edition. Montana Fish, Wildlife, and Parks, Helena.

Jessup, B., J. Stribling; and C. Hawkins. 2005. Biological Indicators of Stream Condition in Montana Using Macroinvertebrates. Tetra Tech, Inc. November 2005 (draft).

Jessup, B. 2006. Ecological Data Application System (EDAS) Version MT 3.3.2k A User's Guide. Tetra Tech, Inc.

Lazorchak, J.M., Klemm, D.J., and D.V. Peck (editors). 1998. Environmental Monitoring and Assessment Program - Surface Waters: Field Operations and Methods for Measuring the Ecological Condition of Wadeable Streams. EPA/620/R-94/004F. U.S. Environmental Protection Agency, Washington, D.C.

Montana Department of Environmental Quality (DEQ). 2005. Sample Collection, Sorting, and Taxonomic Identification of Benthic Macroinvertebrates. Water Quality Planning Bureau. Standard Operation Procedure (WQPBWQM-009).

Stagliano, David, M. 2005. Aquatic Community Classification and Ecosystem Diversity in Montana's Missouri River Watershed. Report to the Bureau of Land Management. Montana Natural Heritage Program, Helena, Montana. 65 pp. plus appendices.

http://www.mtnhp.org/reports.asp\#Ecology 
Appendix A. Macroinvertebrate Species List for all Centennial samples. Number of individuals (abundance) collected at each site. Grey Shaded =Spring Indicator taxa. Underlined = Coldwater Dependent taxa, Red Shaded are introduced species.

\begin{tabular}{|c|c|c|c|}
\hline Site Name & site_code & Taxon & Abundance \\
\hline Dulany Spring & UM_S0256 & Argia & 20 \\
\hline Dulany Spring & UM_S0256 & Chimarra cf. utahensis & 25 \\
\hline Dulany Spring & UM_S0256 & Corynoneura & 1 \\
\hline Dulany Spring & UM_S0256 & Cricotopus & 13 \\
\hline Dulany Spring & UM_S0256 & Enallagma & 4 \\
\hline Dulany Spring & UM_S0256 & Erpobdella & 1 \\
\hline Dulany Spring & UM_S0256 & Fallceon quilleri & 4 \\
\hline Dulany Spring & UM_S0256 & Gyraulus parvus & 15 \\
\hline Dulany Spring & UM_S0256 & Hydrobius & 3 \\
\hline Dulany Spring & UM_S0256 & Libellula & 2 \\
\hline Dulany Spring & UM_S0256 & Micropsectra & 3 \\
\hline Dulany Spring & UM_S0256 & Ochrotrichia & 1 \\
\hline Dulany Spring & UM_S0256 & Ophiogomphus severus & 4 \\
\hline Dulany Spring & UM_S0256 & Paramerina & 9 \\
\hline Dulany Spring & UM_S0256 & Physella & 22 \\
\hline Dulany Spring & UM_S0256 & Pseudochironomus & 7 \\
\hline Dulany Spring & UM_S0256 & Radotanypus & 12 \\
\hline Dulany Spring & UM_S0256 & Sciomyzidae & 3 \\
\hline Dulany Spring & UM_S0256 & Simulium & 1 \\
\hline Dulany Spring & UM_S0256 & Sphaerium & 2 \\
\hline Dulany Spring & UM_S0256 & Thienemannimyia gr. & 5 \\
\hline Dulany Spring & UM_S0256 & Tubificidae & 1 \\
\hline Metzel Spring & UM_S0257 & Argia & 52 \\
\hline Metzel Spring & UM_S0257 & Chimarra utahensis & 14 \\
\hline Metzel Spring & UM_S0257 & Cricotopus & 16 \\
\hline Metzel Spring & UM_S0257 & Cricotopus bicinctus gr. & 3 \\
\hline Metzel Spring & UM_S0257 & Enallagma & 2 \\
\hline Metzel Spring & UM_S0257 & Fallceon quilleri & 6 \\
\hline Metzel Spring & UM_S0257 & Fossaria & 2 \\
\hline Metzel Spring & UM_S0257 & Helicopsyche borealis & 63 \\
\hline Metzel Spring & UM_S0257 & Helophorus & 1 \\
\hline Metzel Spring & UM_S0257 & Libellula & 4 \\
\hline Metzel Spring & UM_S0257 & Ochrotrichia & 2 \\
\hline Metzel Spring & UM_S0257 & Paramerina & 4 \\
\hline Metzel Spring & UM_S0257 & Physella & 39 \\
\hline Metzel Spring & UM_S0257 & Pseudochironomus & 10 \\
\hline Metzel Spring & UM_S0257 & Rheocricotopus & 1 \\
\hline Metzel Spring & UM_S0257 & Stratiomys & 2 \\
\hline Metzel Spring & UM_S0257 & Thienemannimyia gr. & 4 \\
\hline Metzel Spring & UM_S0257 & Tubificidae & 20 \\
\hline Metzel Spring & UM_S0257 & Tvetenia bavarica Gr. & 2 \\
\hline Metzel Creek @ Road & UM_S0258 & Argia & 12 \\
\hline Metzel Creek @ Road & UM_S0258 & Cricotopus & 21 \\
\hline
\end{tabular}




\begin{tabular}{|c|c|c|c|}
\hline Metzel Creek @ Road & UM_S0258 & Fossaria obrussa & 4 \\
\hline Metzel Creek @ Road & UM_S0258 & Gyraulus & 3 \\
\hline Metzel Creek @ Road & UM_S0258 & Hesperophylax & 3 \\
\hline Metzel Creek @ Road & UM_S0258 & Hyalella azteca & 21 \\
\hline Metzel Creek @ Road & UM_S0258 & Hydrobius & 1 \\
\hline Metzel Creek @ Road & UM_S0258 & Hydroptila & 5 \\
\hline Metzel Creek@ Road & UM_S0258 & Parametriocnemus & 1 \\
\hline Metzel Creek@ Road & UM_S0258 & Physella & 83 \\
\hline Metzel Creek@ Road & UM_S0258 & Psychoronia & 2 \\
\hline Fish Creek upstream & UM s0258up & Ameletus & $\underline{1}$ \\
\hline$\overline{\text { Fish Creek upstream }}$ & $\overline{\text { UM_S0258up }}$ & Antocha & $\overline{1}$ \\
\hline Fish Creek upstream & UM_S0258up & Baetis tricaudatus & 87 \\
\hline Fish Creek upstream & UM_S0258up & Brachycentrus americanus & 22 \\
\hline Fish Creek upstream & UM_S0258up & Cinygmula & 12 \\
\hline Fish Creek upstream & UM S0258up & Drunella doddsi & $\underline{2}$ \\
\hline$\overline{\text { Fish Creek upstream }}$ & UM S0258up & Drunella grandis & $\underline{\overline{6}}$ \\
\hline Fish Creek upstream & UM S0258up & Ephemerella excrucians & $\underline{34}$ \\
\hline$\overline{\text { Fish Creek upstream }}$ & UM S0258up & Helicopsyche borealis & $\underline{54}$ \\
\hline Fish Creek upstream & UM S0258up & $\overline{\text { Hesperoperla pacifica }}$ & $\overline{4}$ \\
\hline$\overline{\text { Fish Creek upstream }}$ & $\overline{\text { UM_S0258up }}$ & Isoperla & $\overline{2}$ \\
\hline Fish Creek upstream & UM_S0258up & Lepidostoma unicolor & 23 \\
\hline Fish Creek upstream & UM_S0258up & Micrasema bactro & 16 \\
\hline Fish Creek upstream & UM_S0258up & Optioservus & 23 \\
\hline Fish Creek upstream & UM_S0258up & Orthocladiinae & 22 \\
\hline Fish Creek upstream & UM_S0258up & Pericoma & 63 \\
\hline Fish Creek upstream & UM S0258up & Rhithrogena & 2 \\
\hline Fish Creek upstream & UM S0258up & Sweltsa & $\underline{\overline{8}}$ \\
\hline$\overline{\text { Fish Creek upstream }}$ & UM_S0258up & $\overline{\text { Taeniopterygidae }}$ & $\overline{1}$ \\
\hline Fish Creek upstream & UM S0258up & Zapada cinctipes & 22 \\
\hline Murphy Creek Spring Headcut & UM_S0261 & $\overline{\text { Argia }}$ & $\overline{12}$ \\
\hline Murphy Creek Spring Headcut & UM_S0261 & Chimarra utahensis & 21 \\
\hline Murphy Creek Spring Headcut & UM_S0261 & Cricotopus & 6 \\
\hline Murphy Creek Spring Headcut & UM_S0261 & Cricotopus trifascia gr. & 3 \\
\hline Murphy Creek Spring Headcut & UM_S0261 & Fallceon quilleri & 23 \\
\hline Murphy Creek Spring Headcut & UM_S0261 & Gyraulus parvus & 7 \\
\hline Murphy Creek Spring Headcut & UM_S0261 & Helicopsyche borealis & 212 \\
\hline Murphy Creek Spring Headcut & UM_S0261 & Hyalella azteca & 12 \\
\hline Murphy Creek Spring Headcut & UM_S0261 & Hydroptila & 7 \\
\hline Murphy Creek Spring Headcut & UM_S0261 & Ochrotrichia & 22 \\
\hline Murphy Creek Spring Headcut & UM_S0261 & Ophiogomphus severus & 9 \\
\hline Murphy Creek Spring Headcut & UM_S0261 & Physella & 12 \\
\hline Murphy Creek Spring Headcut & UM_S0261 & Radotanypus & 5 \\
\hline Murphy Creek Spring Headcut & UM_S0261 & Simulium & 15 \\
\hline Murphy Creek Spring down & UM_S0259 & Argia & 30 \\
\hline Murphy Creek Spring down & UM_S0259 & Chimarra utahensis & 55 \\
\hline Murphy Creek Spring down & UM_S0259 & Cricotopus & 2 \\
\hline Murphy Creek Spring down & UM_S0259 & Cricotopus trifascia gr. & 2 \\
\hline Murphy Creek Spring down & UM_S0259 & Fallceon quilleri & 2 \\
\hline Murphy Creek Spring down & UM_S0259 & Gyraulus & 3 \\
\hline
\end{tabular}




\begin{tabular}{|c|c|c|c|}
\hline Murphy Creek Spring down & UM_S0259 & Helicopsyche borealis & 125 \\
\hline Murphy Creek Spring down & UM_S0259 & Hyalella azteca & 21 \\
\hline Murphy Creek Spring down & UM_S0259 & Hydroptila & 26 \\
\hline Murphy Creek Spring down & UM_S0259 & Ochrotrichia & 3 \\
\hline Murphy Creek Spring down & UM_S0259 & Ophiogomphus severus & 21 \\
\hline Murphy Creek Spring down & UM_S0259 & Paramerina & 3 \\
\hline Murphy Creek Spring down & UM_S0259 & Physella & 12 \\
\hline Murphy Creek Spring down & UM_S0259 & Simulium & 2 \\
\hline Murphy Creek Spring down & UM_S0259 & Tubificidae & 2 \\
\hline Murphy Creek Spring mid-way & UM_S0260 & Argia & 43 \\
\hline Murphy Creek Spring mid-way & UM_S0260 & Chimarra utahensis & 45 \\
\hline Murphy Creek Spring mid-way & UM_S0260 & Cricotopus & 6 \\
\hline Murphy Creek Spring mid-way & UM_S0260 & Cricotopus trifascia gr. & 3 \\
\hline Murphy Creek Spring mid-way & UM_S0260 & Fallceon quilleri & 4 \\
\hline Murphy Creek Spring mid-way & UM_S0260 & Gyraulus parvus & 3 \\
\hline Murphy Creek Spring mid-way & UM_S0260 & Helicopsyche borealis & 144 \\
\hline Murphy Creek Spring mid-way & UM_S0260 & Hyalella azteca & 33 \\
\hline Murphy Creek Spring mid-way & UM_S0260 & Hydroptila & 21 \\
\hline Murphy Creek Spring mid-way & UM_S0260 & Ochrotrichia & 13 \\
\hline Murphy Creek Spring mid-way & UM_S0260 & Ophiogomphus severus & 16 \\
\hline Murphy Creek Spring mid-way & UM_S0260 & Paramerina & 3 \\
\hline Murphy Creek Spring mid-way & UM_S0260 & Physella & 22 \\
\hline Murphy Creek Spring mid-way & UM_S0260 & Radotanypus & 1 \\
\hline Murphy Creek Spring mid-way & UM_S0260 & Simulium & 4 \\
\hline Murphy Creek Spring mid-way & UM_S0260 & Tubificidae & 6 \\
\hline Hellroaring Spring & UM_S0263 & Baetis tricaudatus & 3 \\
\hline Hellroaring Spring & UM_S0263 & Cricotopus & 8 \\
\hline Hellroaring Spring & UM_S0263 & Diamesa & 11 \\
\hline Hellroaring Spring & UM_S0263 & Eukiefferiella pseudomontana & 17 \\
\hline Hellroaring Spring & UM S0263 & Hesperophylax designatus & $\underline{9}$ \\
\hline Hellroaring Spring & UM_S0263 & Heterlimnius corpulentus & 47 \\
\hline Hellroaring Spring & UM_S0263 & Hydrobaenus & 3 \\
\hline Hellroaring Spring & $\underline{\text { UM S0263 }}$ & Neophylax rickeri & $\underline{40}$ \\
\hline Hellroaring Spring & $\underline{\text { UM S0263 }}$ & Neophylax splendens & $\underline{9}$ \\
\hline Hellroaring Spring & UM_S0263 & Pagastia & 128 \\
\hline Hellroaring Spring & $\underline{\text { UM S0263 }}$ & Polycelis coronata & $\underline{14}$ \\
\hline Hellroaring Spring & UM_S0263 & Rhyacophila brunnea gr. & 1 \\
\hline Hellroaring Spring & $\underline{\text { UM S0263 }}$ & Sweltsa & $\underline{6}$ \\
\hline Hellroaring Spring & $\overline{\text { UM_S0263 }}$ & $\overline{\text { Thienemanniella }}$ & $\overline{1}$ \\
\hline Hellroaring Spring & UM_S0263 & Tipula & 1 \\
\hline Tepee Creek & UM_S0269 & Callibaetis & 12 \\
\hline Tepee Creek & UM_S0269 & Corixidae & 22 \\
\hline Tepee Creek & UM_S0269 & Dicrotendipes & 11 \\
\hline Tepee Creek & UM_S0269 & Leptophlebia cupida & 5 \\
\hline Tepee Creek & UM_S0269 & Notonecta & 2 \\
\hline Tepee Creek & UM_S0269 & Odontomyia & 2 \\
\hline Tepee Creek & UM_S0269 & Psectrocladius & 23 \\
\hline Tepee Creek & UM_S0269 & Stagnicola elodes & 20 \\
\hline Tepee Creek & UM_S0269 & Stratiomys & 5 \\
\hline
\end{tabular}


